\section{POLA ASUH OTORITER ORANG TUA DAN PERILAKU KENAKALAN [DELINQUENCY] PADA REMAJA}

Pentingnya pola asuh orang tua terhadap anak yang beranjak remaja adalah sebuah tantangan terbesar buat para orang tua. Setiap orangtua tentunya ingin memberikan yang terbaik bagi anak-anak mereka. Keinginan ini kemudian akan membentuk pola asuh yang akan ditanamkan orangtua kepada anak-anak. Anak yang diasuh dengan pola asuh yang baik maka anak akan tumbuh menjadi pribadi yang baik. Sebaliknya, anak yang diasuh dengan pola asuh yang buruk akan tumbuh menjadi anak dengan pribadi yang buruk sehingga akan terjadilah kenakalan remaja.

Seiring dengan perkembangan zaman, terdapat banyak sekali jenis kenakalan remaja dari tingkat yang ringan sampai yang tergolong berat. Kenakalan remaja yang dapat kita jumpai diantaranya seperti, sering bolos sekolah dan tawuran antar sekolah dsb. Yang tentu saja perbuatan tersebut sangat tidak baik untuk dilakukan. Kenakalan remaja sendiri merupakan perbuatan yang melanggar aturan, hukum ataupun norma yang ada di dalam masyarakat yang dilakukan di waktu usia remaja.

Buku ini memberikan gambaran mengenai menerapkan pola asuh otoriter bukanlah penyebab dari kenakalan remaja itu sendiri, karena kenakalan remaja sendiri juga disebabkan oleh beberapa faktor yaitu faktor internal dan eksternal antara lain: faktor internal misalnya Krisis identitas dan Kontrol diri yang lemah, sedangkan faktor eksternal misalnya broken home, Teman sebaya yang kurang baik atau berada di circle pertemanan yang buruk, Komunitas atau lingkungan tempat tinggal yang kurang baik, atau perselisihan antar anggota keluarga yang bisa memicu perilaku negatif pada remaja, orangtua terlalu memanjakan anak, tidak memberikan pendidikan agama, atau penolakan terhadap eksistensi anak, yang dapat menjadi penyebab terjadinya kenakalan remaja. Buku ini juga wajib dijadikan referensi dan informasi bagi para orangtua, sekolah dan masyarakat lainnya.
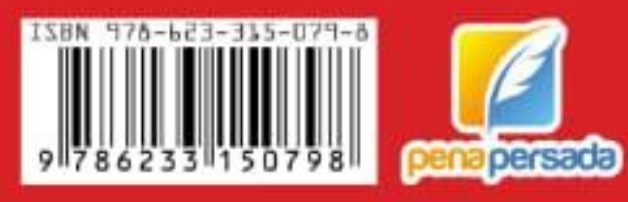

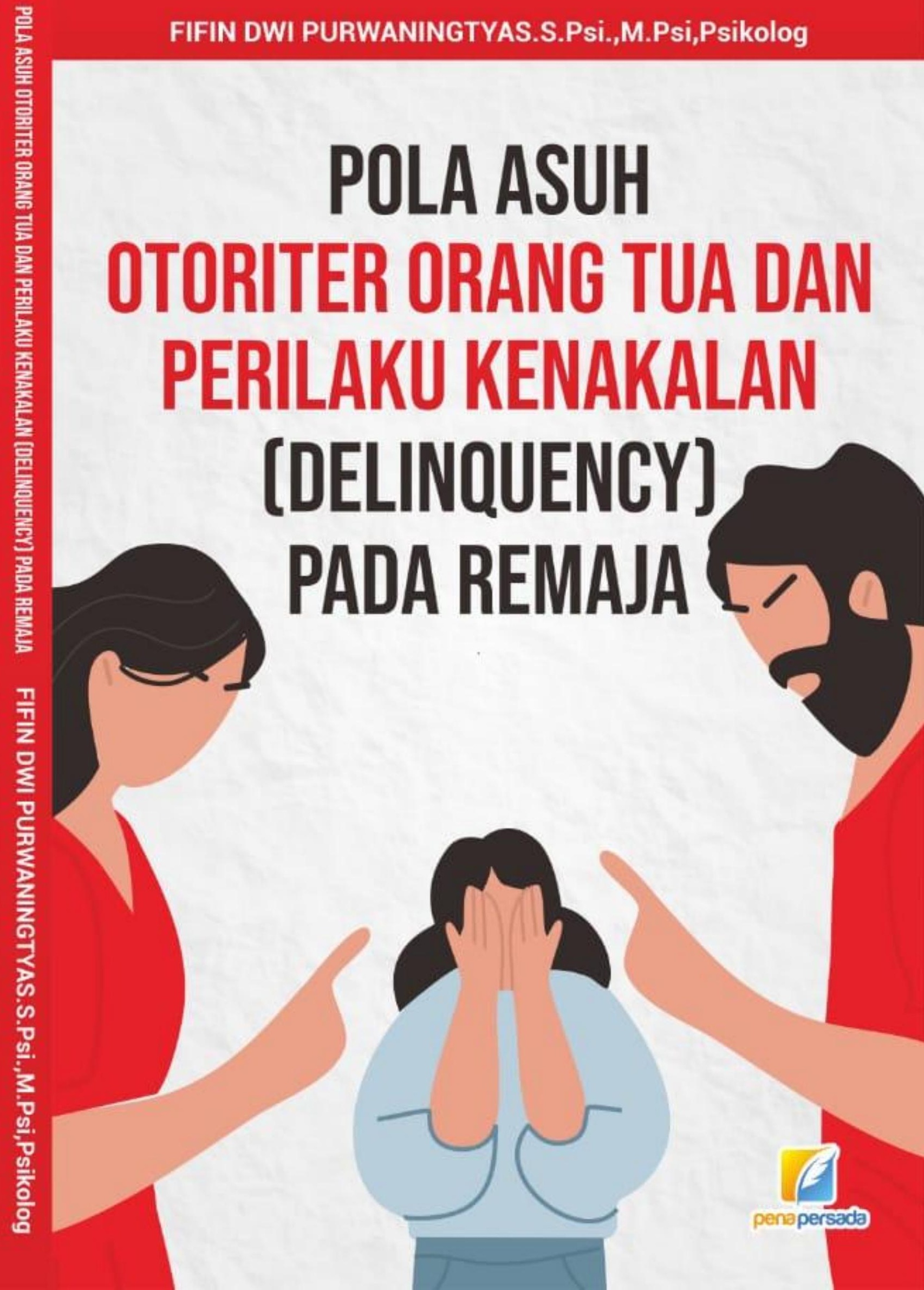




\section{POLA ASUH OTORITER ORANG TUA DAN PERILAKU KENAKALAN (DELINQUENCY) PADA REMAJA}

FIFIN DWI PURWANINGTYAS, S.Psi., M.Psi, Psikolog

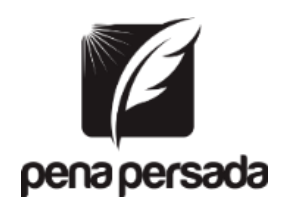

PENERBIT CV. PENA PERSADA 


\section{POLA ASUH OTORITER ORANG TUA DAN PERILAKU KENAKALAN (DELINQUENCY) PADA REMAJA}

\section{Penulis:}

Fifin Dwi Purwaningtyas, S.Psi., M.Psi, Psikolog

Editor :

Tri Hidayati

ISBN : 978-623-315-079-8

Design Cover :

Retnani Nur Briliant

Layout :

Eka Safitry

\section{Penerbit CV. Pena Persada}

Redaksi :

Jl. Gerilya No. 292 Purwokerto Selatan, Kab. Banyumas Jawa Tengah

Email : penerbit.penapersada@gmail.com

Website : penapersada.com Phone : (0281) 7771388

\section{Anggota IKAPI}

All right reserved

Cetakan pertama : 2020

Hak Cipta dilindungi oleh undang-undang. Dilarang memperbanyak karya tulis ini dalam bentuk apapun tanpa izin penerbit 


\section{KATA PENGANTAR}

Puji syukur saya panjatkan kepada Tuhan Yang Maha Esa, karena atas berkat dan rahmat-Nya, saya dapat menyelesaikan buku ini. Penulisan buku merupakan buah karya dari pemikiran penulis yang diberi judul "Pola Asuh Otoriter Orang Tua dan Perilaku Kenakalan (Delinquency) Pada Remaja". Saya menyadari bahwa tanpa bantuan dan bimbingan dari berbagai pihak sangatlah sulit bagi saya untuk menyelesaikan karya ini. Oleh karena itu, saya mengucapkan banyak terima kasih pada semua pihak yang telah membantu penyusunan buku ini. Sehingga buku ini bisa hadir di hadapan pembaca.

Kajian dalam buku ini bertujuan untuk mengetahui apakah ada hubungan antara persepsi terhadap pola asuh otoriter orang tua dengan perilaku Kenakalan (Delinquency) pada Remaja di SMU X Surabaya. Kenakalan remaja adalah suatu bentuk tingkah laku yang dilakukan oleh remaja yang berusia dibawah 18 tahun yang bersifat merugikan diri sendiri maupun orang lain dan melanggar peraturan tetapi tidak dikenakan hukuman. Sedangkan Persepsi terhadap pola asuh otoriter orang tua adalah suatu persepsi anak mengenai pola asuh yang diterapkan orang tua terhadap anak-anak yaitu dengan orang tua yang mengharapkan, menghukum dan menuntut kepatuhan dari seorang anak. Pola asuh ini tergolong sulit terutama bagi remaja yang cenderung memberontak melawan pengasuhan otoriter. Sehingga hanya ada satu variabel independen dan satu variabel dependen yang akan diselidiki hubungannya dalam kajian di buku ini.

Kajian dilakukan pada Remaja awal yang bersekolah di SMU X Surabaya. Jumlah subjek yang digunakan adalah 70 orang. yang meliputi perempuan 41 dan laki-laki 29. Teknik sampling yang digunakan purposive sampling. Alat pengumpul data berupa kuesioner persepsi pola asuh otoriter sebagai screening yang terdiri 20 butir yang disusun sendiri oleh peneliti dan alat ukur kenakalan remaja yang terdiri 47 butir yang disusun sendiri. Analisa data yang digunakan adalah teknik statistik korelasi spearman rank dengan bantuan program statistik SPSS versi 16.00 
for Windows. Hasil kajian menunjukkan bahwa tidak terdapat ada hubungan yang signifikan antara persepsi pola asuh otoriter orang tua dengan perilaku kenakalan (Delinquency) remaja di SMU X Surabaya.

Penulis menyadari bahwa buku ini masih jauh dari kesempurnaan. Oleh karena itu kritik dan saran yang membangun sangat dibutuhkan guna penyempurnaan buku ini. Akhir kata saya berharap Tuhan Yang Maha Esa berkenan membalas segala kebaikan semua pihak yang telah membantu. Semoga buku ini akan membawa manfaat bagi pengembangan ilmu dibidang Psikologi Pendidikan, Psikologi Klinis dan Psikologi Perkembangan. 


\section{DAFTAR ISI}

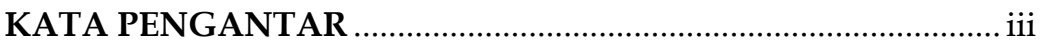

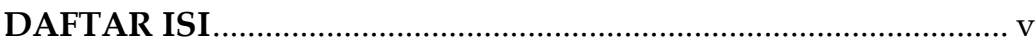

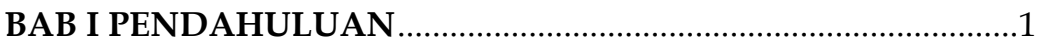

A. Persoalan Masa Remaja ...........................................................1

B. Persoalan Pola Asuh Orang Tua .................................................

BAB II KENAKALAN REMAJA (DELINQUENCY) .....................12

A. Pengertian Kenakalan Remaja (DELINQUENCY) ...............12

B. Bentuk dan Aspek-Aspek Kenakalan Remaja.......................13

C. Karakteristik Remaja Nakal ....................................................18

D. Faktor-Faktor Yang Mempengaruhi Kenakalan Remaja ...19

BAB III TEORI TENTANG PERSEPSI ..........................................29

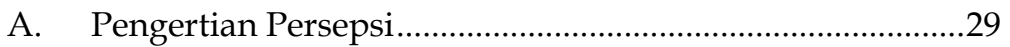

B. Proses Persepsi ....................................................................29

BAB IV POLA ASUH ORANG TUA...............................................

A. Pengertian Pola Asuh Orang Tua ............................................31

B. Bentuk Pola Asuh Orang Tua................................................32

C. Faktor-Faktor yang mempengaruhi Pola Asuh Orang Tua

D. Macam-macam Pola Asuh Orang Tua ..................................32

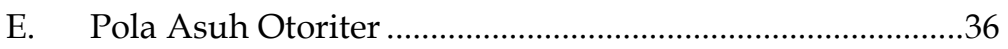

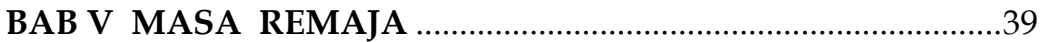

A. Pengertian Remaja …………………………......................39

B. Karakteristik Umum Remaja Awal ........................................40

C. Persepsi Remaja Terhadap Pola Asuh Otoriter Orang Tua.

1. Gambaran Umum ...............................................................46 
2. Pengertian Persepsi Remaja terhadap Pola Asuh Otoriter

D. Hubungan Bentuk Pola Asuh Otoriter Dengan Kenakalan (Delinquency) Pada Remaja.

BAB VI GAMBARAN UMUM DAN ANALISIS DESKRIPTIF POLA ASUH ORANG TUA \& KENAKALAN REMAJA ..............49

A. Gambaran Umum Sekolah ...................................................49

B. Analisis Deskriptif Pola Asuh Orang Tua \& Kenakalan

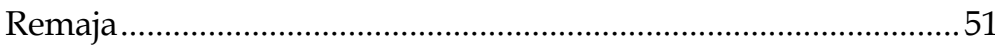

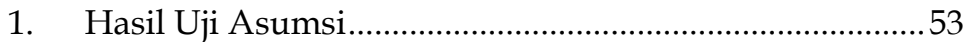

BAB VII GAMBARAN PERSEPSI POLA ASUH DAN

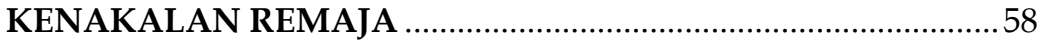

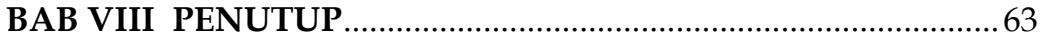

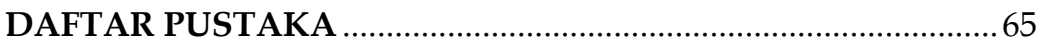

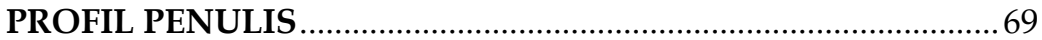




\section{BAB I \\ PENDAHULUAN}

\section{A. Persoalan Masa Remaja}

Masa remaja adalah masa peralihan dari anak menuju dewasa (Hurlock, 1997: 85), disebut masa peralihan karena pada fase ini remaja secara fisik telah mengalami perkembangan sebagaimana layaknya orang dewasa dan perkembangan fisik ini selanjutnya mengarahkan remaja kepada pembentukan dan pencarian identitas dirinya (Santrock, 2003: 79). Perkembangan fisik membuat remaja merasa dirinya telah dewasa dan harus mendapat peran yang sama sebagaimana orang dewasa dalam membuat keputusan, menentukan kegiatan, menentukan tempat sekolah dan lain sebagainya. Sementara disisi lain perkembangan fisik yang telah matang pada remaja tersebut seringkali tidak diikuti dengan kematangan emosi, kognitif dan ranah psikologis yang lain, sehingga para orang dewasa masih menganggap mereka sebagai anak-anak yang membutuhkan pengasuhan bukan dukungan, yang membutuhkan perlindungan bukan bimbingan dan membutuhkan sosialisasi bukan pengarahan. Kekaburan peran ini menjadikan masa remaja menjadi masa yang penuh dengan goncangan, masa peralihan dan masa pencarian identitas (Hurlock, 1997: 95 \& Monks, 2002: 78).

Remaja merupakan pewaris negara kita pada masa akan datang. Berbagai harapan diletakkan agar mereka berupaya menjadi individu yang berguna serta mampu menyumbang kearah kesejahteraan negara secara seluruhannya. Namun pada kenyataannya, sejak akhir-akhir ini berbagai pihak menaruh harapan yang tidak pasti tentang gejala sosial yang sedang melanda para remaja, sama halnya disadari atau tidak disadari, suatu perkembangan yang muncul gejala sosial, maka semakin meningkat dari hari ke hari. Setiap hari dilihatkan berbagai cerita tentang berbagai 
tingkah laku yang dilakukan oleh remaja baik tingkah laku yang kecil maupun besar. Pada dasarnya faktor-faktor penyebab perilaku kenakalan remaja terdiri atas akumulasi berbagai macam faktor, baik internal maupun eksternal, seperti: pola asuh orang tua, lingkungan rumah, lingkungan sekolah dan lingkungan sosial.

Media-media massa seringkali menyiarkan berbagai berita dan cerita tentang kenakalan remaja yang masih bersekolah dan berbagai masalah sosial yang melibatkan mereka. Masalah ini turut membimbangkan berbagai pihak, khususnya pemerintah, masyarakat, guru, orang tua sendiri. Menurut Kvaraceus membagi bentuk kenakalan menjadi dua, yaitu contohnya, kasus kenakalan biasa seperti: Berbohong, membolos sekolah, meninggalkan rumah tanpa izin (kabur), keluyuran, memiliki dan membawa benda tajam, bergaul dengan teman yang memberi pengaruh buruk, berpesta pora, membaca buku-buku cabul, turut dalam pelacuran atau melacurkan diri, berpakaian tidak pantas dan minum minuman keras. Kenakalan pelanggaran hukum, seperti: berjudi, mencuri, mencopet, menjambret, merampas, penggelapan barang, penipuan dan pemalsuan, menjual gambar-gambar porno dan film-film porno, pemerkosaan, pemalsuan uang, perbuatan yang merugikan orang lain, pembunuhan dan pengguguran kandungan. (Mulyono, 1995: 90).

Ketika remaja tidak dapat berpikir secara abstrak mereka juga tidak memiliki idealisme dalam diri mereka sehingga menyebabkan mereka melakukan segala hal tanpa berpikir secara logis. Seorang remaja yang tidak berpikir secara abstrak hanya dapat melakukan suatu hal berdasarkan dari pengalaman nyata mereka saja sehingga, membuat mereka tidak memiliki idealisme sendiri tapi cenderung lebih memilih untuk memenuhi idealisme orang lain, ketika mereka tidak mampu memenuhi idealisme tersebut mereka akan melakukan segala hal agar tujuan mereka bisa tercapai bahkan, jika harus melanggar peraturan sekali pun maka 
mereka akan melakukan agar idealisme tersebut dapat mereka capai. Dari sini kita dapat melihat bahwa remaja sudah tidak dapat berpikir secara logis, karena mereka merasa tidak mampu. Memenuhi idealisme yang di anut membuat remaja melakukan segala hal walaupun yang mereka lakukan melanggar peraturan sekalipun sehingga, munculnya sebuah perilaku yang tidak diterima secara sosial, melanggar peraturan hingga kriminal yang kita sebut sebagai kenakalan remaja. Kenakalan remaja atau yang juga disebut delinquency merupakan sebuah perilaku remaja yang mengacu pada suatu rentang perilaku yang luas, mulai dari perilaku yang tidak dapat diterima secara sosial, pelanggaran hingga tindakan kriminal (Santrock, 1995: 92).

Munculnya fenomena kenakalan remaja merupakan salah satu masalah yang diakibatkan karena remaja mengalami ketidakmampuan dalam menjalankan tugas perkembangan sehingga mengakibatkan timbulnya perilaku menyimpang yang mengarah pada tindakan-tindakan yang melanggar peraturan. Delinkuensi itu selalu mempunyai konotasi serangan kejahatan, keganasan dan pelanggaran terhadap norma-norma sosial dan hukum yang dilakukan oleh anak-anak muda di bawah usia 22 tahun. Masih menurut Kartono (2006: 50) kasus delinkuensi paling banyak dialami remaja berusia dibawah 21 tahun, dan angka tertinggi delinkuensi remaja terdapat pada usia 15-19 tahun. Dari berbagai definsi di atas tentang kenakalan remaja dapat ditarik kesimpulan bahwa kenakalan remaja adalah perilaku yang dapat menyakiti atau merugikan dirinya sendiri atau orang lain dengan melanggar norma-norma hukum, agama, kelompok, sosial seperti penyalahgunaan obat-obatan terlarang dan membolos.

\section{B. Persoalan Pola Asuh Orang Tua}

Serta pada data observasi kenyataannya SMU yang di ambil lokasi sekolahnya berdekatan dengan banyak mall sehingga, siswa dapat membolos pada saat jam waktu sekolah. Penulis sempat mewawancari salah satu guru yang 
ada disekolah tersebut, mengenai seluk-beluk siswa, dan guru tersebut menyatakan bahwa siswa yang nakal masih dalam kategori yang wajar diperkirakan $45 \%$, hal yang biasanya dilakukan oleh siswa di sini misalnya: merokok, membolos, memakai baju sekolah yang ketat, dan datang terlambat. Tidak itu saja menurut pandangan orang yang pernah bersekolah disana yang sekarang menjadi alumni mengatakan:

"bahwa yang bersekolah disini termasuk sekolah swasta yang elit, dan sekolah sini belum pernah terlibat tawuran (perkelahian) antar sekolah lain, hanya melakukan kenakalan yang biasa saja misalnya: merokok, datang terlambat, tidak pernah masuk sekolah, dan membolos. Serta guru kami juga sering mengadakan pengeledahan barang-barang yang termasuk barang terlarang dan video porno, jadinya kami sebagai siswa tidak berani untuk membawa dan memakainya".

Studi Arifin \& Hambali, (dalam Shochib, 2000: 4) membuktikan bahwa kenakalan remaja diwilayah jawa timur disebabkan oleh kondisi keluarga yang negatif, seperti ketegangan keluarga, tingkat otoritas orang tua, dan miskinnya teladan keagamaan. Diantara ketiga faktor tersebut, faktor dominan adalah kemiskinannya teladan keagamaan dari orang tua.

Menurut Turner \& Helms, (dalam Dariyo, 2004; 111112), Penerapan disiplin keluarga yang tidak tepat bisa memungkinkan sebagian dari orang tua beranggapan, bahwa menerapkan kedisiplinan terhadap anak-anak berarti harus melakukannya dengan tegas, keras, tidak kenal kompromi serta tidak mengenal belas kasihan kepada anak. Di sini, orang tua berperan secara sentral dalam menentukan kriteria kedisiplinan. Ketika anak sering memperoleh perlakukan kasar dan keras dari orang tua, mungkin anak akan taat dan patuh dihadapan orang tua. Akan tetapi, sifat kepatuhan itu semu dan sementara. Mereka cenderung akan melakukan tindakan-tindakan yang negatif, sebagai pelarian maupun protes terhadap orang tuanya. Misalnya dengan melakukan 
tindakan anarkis, melawan hukum, terlibat kenakalan, antisosial dan sebagainya.

Menurut Agnew Pengaruh negatif yang timbul jika orang tua menggunakan hukuman badan yang tidak konsisten terhadap anak adalah kenakalan remaja yang semakin menjadi (Shochib, 2000: 8). Hukuman pun dapat menjadi pemicu kenakalan remaja jika orang tua memberikan hukuman yang kurang tepat kepada anak. Hukuman yang hanya ditekankan dari segi hukuman dan bukan tujuannya, oleh anak tidak akan dihayati sebagai bantuan tetapi penyiksaan.

Menurut Hamidah (2002: 125), hampir setiap orang tua mengharapkan anaknya menjadi anak yang baik yang sesuai dengan harapan orang tua khususnya dan masyarakat pada umumnya, taat dan patuh pada nilai-nilai yang berlaku bagi masyarakat dan menjadi orang yang bermanfaat baik bagi dirinya, keluarganya dan lingkungannya. Harapan ini mendorong setiap orang tua memberikan yang terbaik untuk anaknya berdasarkan pendapat, pemahaman dan pengetahuannya. Sayangnya hal yang dianggap terbaik oleh orang tua belum tentu menjadi yang terbaik bagi anak-anak mereka karena hal ini dipengaruhi oleh banyak faktor. Perbedaan hasil inilah yang seringkali membuat orang tua menjadi bingung, tidak tahu apa yang harus dilakukan karena kurang memahami apa yang menjadi penyebab perbedaan serta kurang mengetahui apa yang diharapkan anak. Oleh karena itu apa yang dianggap baik oleh orang tua menjadi cara atau jalan keluar yang tidak sesuai dengan kebutuhan anak-anak mereka. Sehingga menurut Hurlock (1993: 20), semakin otoriter maka anak menjadi nakal, semakin mendendam anak itu dan sengaja tidak patuh. Perilaku menentang sangat besar pengaruhnya dalam suatu hubungan orang tua dan anak dengan bertambahnya usia anak.

Dalam pola asuh orang tua yang bersifat otoriter segala sesuatunya harus taat dan patuh sesuai dengan apa yang 
telah ditentukan oleh orang tua, sehingga anak tidak boleh bahkan tidak bisa untuk berkutik barang sedikitpun. Maka pada pola asuh orang tua yang bersifat otoriter anak akan selalu merasa ketakutan. Menurut Baldwin (dalam Gerungan, 1996:190) mengatakan, bahwa makin otoriter orang tuanya, maka makin berkuranglah ketidaktaatan anak, tetapi akan makin banyak timbul sifat yang pasif, kurang inisiatif, tidak dapat merencanakan sesuatu, daya tahan berkurang dan menjadi anak yang penakut.

Melihat kenyataan di atas maka Hamidah (2002: 145), menilai pola asuh orang tua akan lebih tepat jika digunakan persepsi anak tentang pola asuh yang diterima dari orang tuanya. Pola asuh orang tua dipandang sebagai suatu respon yang di dalamnya terkandung suatu penilaian, kesan, pendapat ataupun perasaan anak terhadap pola asuh orang tua yang diberikan oleh orang tua mereka. Jadi dapatlah dikatakan bahwa persepsi anak terhadap pola asuh orang tua tersebut sifatnya sangat subyektif. Jadi sesungguhnya yang lebih berpengaruh terhadap perkembangan anak adalah bukan hanya pola asuhnya tetapi persepsi anak terhadap pola asuh tersebut, oleh karena itu kebenaran dan ketepatan persepsi ini menjadi hal yang penting untuk diperhatikan.

Persepsi merupakan salah satu faktor dari efektifitas komunikasi interpersonal. Rakhmat (2003: 45) menjelaskan dengan beberapa contoh seperti, bila seseorang diberitahu bahwa dosennya yang baru itu galak dan tidak senang dikritik maka seseorang itu akan berhati-hati dalam mengajukan pertanyaan. Bila seseorang menganggap tetangganya sombong dan feodal, maka akan menghindari bercakap- cakap dengan dia. Lalu, bila seseorang mempersepsikan kawannya sebagai orang cerdas, bijak, dan senang membantu maka dia akan banyak meminta bantuan nasihat kepadanya. Sama halnya bila seorang anak mempersepsikan pola asuh orang tuanya sebagai pola asuh otoriter maka anak akan memiliki perasaan dendam dan tidak patuh secara sengaja sehingga bila kedua belah pihak 
menanggapi yang lain secara tidak cermat, terjadilah kegagalan komunikasi. Hal inilah yang menyebabkan komunikasi tidak efektif karena menurut Mulyana, (2001: 50), komunikasi yang efektif pada dasarnya adalah berusaha memahami apa yang menyebabkan orang lain berperilaku sebagaimana yang ia lakukan, mana mungkin seorang anak dapat berusaha melakukan apa yang diinginkan orang tuanya jika mereka (anak) mempersepsikan pengasuhan orang tua mereka dengan otoriter sehingga menyebabkan anak akan menjadi patuh kalau di hadapan orang tua, tetapi di belakang orang tuanya ia akan memperlihatkan reaksi-reaksi menentang atau melawan karena anak merasa dipaksa (Sianawati, 1992: 20). Hal ini dapat menimbulkan masalah dan kesulitan bagi diri anak sendiri maupun lingkungannya.

Setiap manusia mempunyai sesuatu yang dikenal dengan istilah persepsi, dan remaja tentu saja juga memiliki hal tersebut. Menurut Levine \& Shefner (Ali dan Asrori, 2004: 192), persepsi adalah cara dalam individu menginterpretasikan informasi yang diperoleh yang didasarkan pada pemahaman individu itu sendiri. Individu sadar akan adanya suatu stimulus namun individu itu menginterpretasikan stimulus tersebut. Melalui persepsi yang telah hadir tersebut, maka terkait dengan adanya suatu keluarga yang merupakan tempat pertama kali bersosialisasi dapat ditelusuri lebih jauh lagi tentang bagaimana persepsi pola asuh yang diterapkan oleh orang tua. Dalam lingkungan keluarga, setiap orang tua menerapkan pola pengasuhan yang tersendiri dan berbeda-beda. Pola pengasuhan orang tua merupakan pola pengasuhan yang dilakukan oleh orang tua terhadap anak dan termasuk dalam pengaruh mikrosistem terhadap perkembangan (Santrock, 2003: 50). Pola asuh ini memainkan peran yang penting dalam perkembangan kepribadian anak karena dari pola asuh yang diterapkan ini kita bisa melihat perkembangan kepribadian anak nantinya, apakah anak itu menjadi seseorang yang otoriter, demokrasi ataupun seseorang yang liberal. Terdapat pola asuh yang 
biasanya diterapkan oleh orang tua dalam mendidik anak mereka, yaitu pola asuh otoriter, demokrasi, dan permisif. Umumnya, pola asuh ini tergantung pada bagaimana cara orang tua itu dibesarkan atau berdasarkan pengalaman temannya yang diketahui berhasil dalam mendidik anak-anak (Hurlock, 1999: 205).

Beberapa faktor yang dapat mempengaruhi persepsi misalnya nilai atau norma yang berlaku dalam masyarakat. Sedangkan persepsi menurut Davidof (dalam Ali\&Asrori, 2004:192) sesungguhnya bukanlah merupakan suatu gambaran yang persis sama dengan realitas yang ada, melainkan gambaran yang perwujudannya sudah diwarnai oleh interpretasi individu. Sama halnya dengan interaksi yang terjadi antara orang tua dan remaja. Para remaja lebih sering menggunakan aspek subjektif ketika berinteraksi dengan orang tua mereka. Aspek subjektif adalah kenyataan nyata yang dipersepsi oleh remaja saat interaksi berlangsung (Ali \& Asrori, 2004: 89). Sehingga yang terjadi adalah timbulnya perbedaan antara pola asuh yang diberikan oleh orang tua dengan persepsi yang diterima oleh remaja terhadap pola asuh orang tua mereka.

Pola pengasuhan orang tua merupakan pola pengasuhan orang tua merupakan pola pengasuhan yang dilakukan oleh orang tua terhadap anak dan termasuk dalam pengaruh mikrosistem terhadap perkembangan (Santrock, 1998:50). Menurut Baumrind, (dalam Olson, 2003: 366-367) mengklasifikasikan empat bentuk pola asuh orang tua, yaitu pola asuh demokratis (democratic), otoriter (authoritarian), permisif (permissive), dan penolakan (rejecting). Pola asuh demokratis memperlihatkan bahwa orang tua membuat peraturan serta harapan-harapan yang jelas dan mendiskusikan hal dengan anak-anak mereka. Sedangkan dalam pola asuh otoriter, orang tua menetapkan peraturan serta harapan-harapan yang kaku dan hal itu dijalankan secara kaku terhadap mereka. Berbeda dengan kedua pola asuh tersebut dalam pola asuh yang permisif orang tua 
membiarkan anak-anak mereka mengambil pilihan sendiri dan jarang memaksa anak-anak mereka untuk memenuhi standar orang tua. Sedangkan dalam pola asuh penolakan, orang tua tidak memberikan perhatian yang cukup terhadap kebutuhan anak-anak mereka dan jarang memiliki harapan terhadap anak-anak mengenai bagaimana seharusnya mereka berperilaku.

Menurut Baumrind (Olson, 2003: 368) telah menyelesaikan beberapa penelitian mengenai hubungan antara empat pola asuh orang tua dengan akibatnya terhadap anak. Secara umum, pola asuh demokratis mengakibatkan anak-anak memilki rasa percaya diri, bersifat periang, dan berorientasi pada prestasi. Selain itu pola asuh ini juga dihubungkan dengan rendahnya tekanan psikologis, tingginya harga diri, rendahnya tingkat penggunaan obatobatan terlarang, dan rendahnya perilaku kenakalan remaja. Anak-anak yang dibesarkan dengan pola asuh lain dinilai lebih ekstrim dalam hal kepaduan dan kemampuan untuk menyesuaikan diri, memilki lebih banyak masalah perilaku, dan rendahnya prestasi akademis.

Sebaliknya, pola asuh otoriter berhubungan dengan lebih tingginya tingkat tekanan psikologis, rendahnya harga diri, dan rendahnya perilaku penyiksaan (Olson, 2003: 368). Pengasuhan yang otoriter diasosiakan dengan inkompetensi sosial anak-anak. Selain itu, anak-anak yang orang tuanya otoriter sering kali juga merasa cemas akan perbandingan sosial, gagal memprakarsi kegiatan, dan memiliki ketrampilan komunikasi yang rendah (Santrock, 2002: 257).

Pola pengasuhan yang baik dari orang tua belum tentu dapat diterima secara baik oleh anak. Hal ini tergantung sepenuhnya pada pemahaman anak terhadap tujuan atas perlakuan yang diberikan oleh orang tuanya. Positif negatifnya sebuah penilaian atau pemahaman terhadap pola asuh tersebut tergantung pada bagaimana anak memandang pola asuh sebagai stimulus yang responnya juga tergantung dari pemahaman anak itu sendiri (Hamidah, 2002: 143). 
Tentu ada suatu hal yang bisa mempengaruhi seorang remaja mengalami kenakalan remaja (Delinquenc)y. Akan tetapi kenyataan bahwa pengaruh seorang remaja yang diasuh secara otoriter oleh orang tua menjadikan mereka kurang memiliki kemampuan secara sosial menimbulkan pertanyaan apakah remaja yang memiliki persepsi bahwa mereka mendapatkan pola asuh otoriter dari orang tua mereka juga dapat mempengaruhi remaja untuk berperilaku nakal. Hal inilah yang mendorong penulis untuk mengkaji hubungan antara persepsi terhadap pola asuh otoriter orang tua dengan perilaku Kenakalan (Delinquency) pada remaja di SMU X Surabaya.

Hal ini menitik beratkan pada pembahasan masalah kenakalan remaja, biasanya kenakalan remaja ini dilakukan oleh remaja yang dipengaruhi oleh beberapa faktor, salah satunya adalah bagaimana orang tua tersebut, menerapkan pola asuh dengan otoriter atau tidak, karena bila pola asuh yang diterapkan adalah pola asuh otoriter maka remaja tersebut mengalami perilaku nakal atau tidak. Sebab dengan adanya sikap otoriter orang tua yang terlalu mengontrol tindakan anak-anaknya maka, anak tersebut menjadi anak yang nakal diluar rumah, hal ini dikarenakan anak tersebut mencari pelarian diluar rumah dengan berbagai cara misalnya berbohong, membolos sekolah, meninggalkan rumah tanpa izin (kabur), keluyuran, memiliki dan membawa benda tajam, bergaul dengan teman yang memberi pengaruh buruk, berpesta pora, dan minum-minuman keras, hal ini yang biasanya remaja dilakukan. Serta remaja sendiri lebih menggunakan aspek subjektifnya dalam menilai interaksi yang terjadi bersama orang tuanya (Fontana, 1981 dalam Ali \& Asrori, 2004:89). Aspek subjektif berarti sudut pandang berasal dari remaja itu sendiri. Dengan begitu perkembangan remaja tidak hanya dipengaruhi oleh bagaimana pola asuh yang diterapkan oleh orang tua akan tetapi juga berkaitan dengan persepsi remaja tentang penerapan pola asuh orang tua tersebut. Menurut suatu penelitian, pola asuh otoriter 
yang diterapkan oleh orang tua dapat diasosiasikan dengan ketidakmampuan anak untuk melakukan sosialisasi. Kemudian timbul pertanyaan ketika remaja mempersepsikan bahwa bentuk pola asuh yang orang tua mereka terapkan adalah pola asuh otoriter, apakah hal ini dapat mempengaruhi mereka berperilaku nakal? Maka selanjutnya hal inilah yang mendorong penulis untuk melakukan kajian mengenai " Hubungan antara persepsi terhadap pola asuh otoriter orang tua dengan perilaku kenakalan (Delinquency) pada remaja di SMU X Surabaya".

Buku ini diharapkan dapat memberikan pengetahuan dan wawasan yang lebih luas bagi kajian ilmu psikologi khususnya Psikologi Perkembangan, Psikologi Klinis, dan Psikologi Sosial khususnya mengenai persepsi anak terhadap pola asuh otoriter orang tua dan kenakalan remaja. Buku ini diharapkan dapat menambah atau pertimbangan bagi temanteman ataupun lainnya yang berminat untuk meneliti lebih jauh tentang variabel atau permasalahan yang sama dengan kajian ini. Selain itu juga diharapkan perlu melakukan kontrol, hal itu dilakukan dengan cara menghomogenkan data pada suatu kajian.

Bahwa pada kenyataannya remaja laki-laki lebih banyak melakukan tingkah laku anti sosial daripada perempuan. pada umumnya jumlah remaja laki-laki yang melakukan kenakalan diperkirakan 50 kali lipat daripada remaja perempuan, hal ini dikarenakan anak laki-laki cenderung suka memberontak apabila tidak sesuai dengan hati nurani, sedangkan perempuan cenderung menjadi penurut dikarenakan perempuan mampu menanamkan nilainilai agama dan moral sebagai pegangan hidupnya. 


\section{BAB II \\ KENAKALAN REMAJA (DELINQUENCY)}

\section{A. Pengertian Kenakalan Remaja (DELINQUENCY)}

Delinquent berasal dari bahasa latin "delinquere" yang berarti terabaikan, mengabaikan, yang kemudian diperluas artinya menjadi jahat, nakal, anti sosial, kriminal, pelanggar aturan, pembuat ribut, pengacau peneror, durjana dan lain sebagainya. Kartono, (2006: 6) mengatakan bahwa kenakalan remaja adalah perilaku jahat yang merupakan gejala sakit (patologis), secara sosial pada anak-anak dan remaja yang disebabkan suatu bentuk pengabaian sosial, sehingga mereka mengembangkan bentuk tingkah laku yang menyimpang tetapi tidak dikenakan hukuman.

Mussen, (1994 :53), mendefinisikan kenakalan remaja sebagai perilaku yang melanggar hukum atau kejahatan yang biasanya dilakukan oleh anak remaja yang berusia 16-18 tahun, jika perbuatan ini dilakukan oleh orang dewasa maka akan mendapat sangsi hukum. Hurlock, (1997: 20) juga menyatakan kenakalan remaja adalah tindakan pelanggaran hukum yang dilakukan oleh remaja, dimana tindakan tersebut dapat membuat seseorang individu yang melakukannya masuk penjara. Sama halnya dengan Dusek, (1977: 56) mendefinisikan kenakalan remaja sebagai suatu kenakalan yang dilakukan oleh seseorang individu yang berumur di bawah 16 dan 18 tahun yang melakukan perilaku yang dapat dikenai sangsi atau hukuman.

Menurut Sarwono, (2002: 67) mengungkapkan kenakalan remaja sebagai tingkah laku yang menyimpang dari norma-norma hukum pidana, sedangkan Fuhrmann (1990: 78) menyebutkan bahwa kenakalan remaja suatu tindakan anak muda yang dapat merusak dan menganggu, baik terhadap diri sendiri maupun orang lain. Santrock, (2003: 100) juga menambahkan kenakalan remaja sebagai kumpulan 
dari berbagai perilaku, dari perilaku yang tidak dapat diterima secara sosial sampai tindakan kriminal. Dari pendapat-pendapat di atas dapat disimpulkan bahwa kecenderungan kenakalan remaja adalah kecenderungan remaja untuk melakukan tindakan yang melanggar aturan yang dapat mengakibatkan kerugian dan kerusakan baik terhadap dirinya sendiri maupun orang lain yang dilakukan remaja di bawah umur 17 tahun.

\section{B. Bentuk dan Aspek-Aspek Kenakalan Remaja}

Menurut Kartono, (2006: 49), bentuk-bentuk perilaku kenakalan remaja dibagi menjadi empat, yaitu :

a. Kenakalan terisolir (Delinkuensi terisolir)

Kelompok ini merupakan jumlah terbesar dari remaja nakal. Pada umumnya mereka tidak menderita kerusakan psikologis. Perbuatan nakal mereka didorong oleh faktor-faktor berikut :

1) Keinginan meniru dan ingin konform dengan genknya, jadi tidak ada motivasi, kecemasan atau konflik batin yang tidak dapat diselesaikan.

2) Mereka kebanyakan berasal dari daerah kota yang transisional sifatnya yang memiliki subkultur kriminal. Sejak kecil remaja melihat adanya genk-genk kriminal, sampai kemudian dia ikut bergabung. Remaja merasa diterima, mendapatkan kedudukan hebat, pengakuan dan prestise tertentu.

3) Pada umumnya remaja berasal dari keluarga berantakan, tidak harmonis, dan mengalami banyak frustasi. Sebagai jalan keluarnya, remaja memuaskan semua kebutuhan dasarnya di tengah lingkungan kriminal. Genk remaja nakal memberikan alternatif hidup yang menyenangkan.

4) Remaja dibesarkan dalam keluarga tanpa atau sedikit sekali mendapatkan supervisi dan latihan kedisiplinan yang teratur, sebagai akibatnya dia tidak sanggup menginternalisasikan norma hidup normal. Ringkasnya, delinkuen terisolasi itu mereaksi terhadap 